\title{
The Travel Agent: Delivering More Value by Becoming an Operational Risk Manager
}

\author{
Debély Joëlle, Dubosson Magali, \\ Fragnière Emmanuel
}

Technical report version of the paper published in the proceedings of the 9th International Research Seminar in Service Management, May 30-31 \& June 1-2 2006 


\title{
The Travel Agent: Delivering More Value by Becoming an Operational Risk Manager
}

\author{
Debély Joëlle \\ Dubosson Magali \\ Fragnière Emmanuel
}

Cahier de recherche

Mai 2007

\begin{abstract}
Résumé
Les voyageurs font face à de nombreux risques ou incertitudes durant toute leur chaîne de service. Soit ils gèrent eux-mêmes ces risques soit ils font appel à une agence de voyages pour les minimiser ou les éviter. Nous pensons que les agences de voyages doivent davantage jouer un rôle de manager de risque que vendeur de prestations pré-préparées. Nous avons proposé un service de management de risque basé sur des approches multidisciplinaires. L'idée est d'appliquer des méthodes d'évaluation de coûts (empruntées des sciences environnementales) pour gérer les risques rencontrés tout le long de la chaîne de voyage.
\end{abstract}

\section{Mots-clés}

Design de service, management du risque, valeur perçue, chaîne de service, agence de voyages

\section{Summary}

Travelers have to handle with various risks and uncertainties by themselves or they can ask a travel agent to act on their behalf in order to minimize and/or to solve them. We believe that the new nature of the activities that could be offered by the travel agencies would rather be a risk management service than just the retailing of prepackaged services. To address this problem of service design, we have conceived a risk management service offer grounded on multidisciplinary approaches. The main idea is to apply cost-based valuation methods to manage the risks arising along the travel chain.

\section{Keywords}

Service design, risk management, perceived risk, service chain, travel agency, surrogate market methods 


\section{Introduction}

Travel agencies are crossing difficult times these days. In the past most of their revenues was generated via commissions they earned by selling airline tickets. Nowadays they must rely on other sources of income in order to survive: the generally adopted pricing scheme is a single fee charged with no link to the service provided to the client. We believe that this single fee approach does not reflect the true value of a typical knowledge-based service.

Travel services encompass the characteristics of typical service activities which are traditionally described with the help of the IHIP paradigm (Intangibility, Heterogeneity, Instantaneity and Perishability). According to the literature, consumers perceive services as riskier than products (Guseman, 1981; Mitchell and Greatorex, 1993; Murray and Schlacter, 1990). Research has shown that intangibility is positively correlated with perceived risk (Finn, 1985; Zeithaml and Bitner, 2000). As stated by Mitchell and Greatorex (1993) "Intangibility ... greatly increases the degree of perceived risk in the purchase of services by decreasing the certainty with which services can be made". Mitchell (1999) affirms that the properties of services may lower consumer confidence and increase perceived risk, mainly by augmenting the degree of uncertainty in the decision. As fairly intangible services, travel services need to be experienced before they can truly be assessed (Parasuraman, Zeithaml \&Berry, 1985; Zeithaml \& Bitner, 2003). They are usually sold without guarantees.

The travel agent purchases travel components in favor of the client. Nor the customers neither the travel agent control most of the risks associated to the various "ingredients". The travel agent's adequate counseling may help the customer to minimize the risk of "travel annoyances". For instance, the expertise of the travel agent could be crucial when determining the convenient connecting times or picking the right hotel. When participating to the design and delivery process, the customer may increase the level of risk if he does not behave appropriately (e.g. not being on time at the airport to catch the plane). Nowadays, a typical client can "assemble" for free a trip using tools available on the Internet, which puts cost pressure on travel agencies. In such environment we wondered whether travel agencies can remain retailers as they used to be and go on selling pre-designed services, or whether they should change the nature of service delivered to the customer.

We propose a methodology to design risk management services that could be provided by the travel agent to the client. Our methodology combines approaches borrowed from the risk management and audit professions as well as research from the environmental sciences and services marketing. The main contribution of this paper is to integrate dollar-based valuation methods, normally used in the valuation of ecological services, to support risk management approaches in the travel service chain. We are discussing here the difficulty of pricing intangible externalities and its consequences, as well as the difficulty of assessing the Willingness To Pay (WTP). We have chosen the replacement cost, substitute cost and damage cost avoided methods because of their simplicity and their wide acceptance. We propose an adaptation of these methods in order to address the operational risks encountered all the way through the travel service chain. 
The paper is organized as follows. In Section 2, we present the difficulties faced by the travel agency business in Switzerland. In Section 3, we present a brief overview of the literature on "perceived risk" in the context of services. In Section 4, we model the "traveler service chain" and explain its particular links with risk events. In Section 5, we present the concept of dollar-based valuation methods and we point out the advantages and drawbacks of these methods. We believe that they could represent a way to improve the perception of risks in the general context of services. In section 6 , we present a framework to design risk management services for travel agencies that is based on the replacement cost, substitute cost and damage cost avoided methods. In Conclusion, we indicate further research directions.

\section{Travel Agencies in Switzerland: An Important Sector in Turmoil}

Travel business went on growing over the years despite fear of natural disasters and terrorism. WTO (World Tourism Organization, www.world-tourism.org/index.htm) estimates that the number of "arrivals" will increase till 2020. Asia would certainly be a big contributor to this development. However, Europe should still remain the biggest player with the largest number of arrivals. In 2004, revenues generated by the European transboarder traffic represented $\$ 262$ billiards. According to OFS (Swiss census data organization, www.bfs.admin.ch), travel agencies inform, counsel, organize travels, provide accommodation and transportation services to the traveler. Moreover, they sometimes act as tour guides. The travel agency industry in Switzerland is made up of a few big players such as Kuoni and Hotelplan and a myriad of small companies. The range of activities varies depending on whether the companies consider themselves as tour operators or retailers, or both of them. All-inclusive tour offering launched in the fifties was a turning point for the travel services industry as today its main activity is to retail packaged vacations that are described in brochures distributed by tour operators.

According to IATA, (International Air Transportation Association, www.iata.org/index.htm) Swiss people spend roughly CHF 3 billiards per year on airline tickets. Bearing in mind the $7 \%$ lost commission, we can estimate the upper bound of foregone revenues opportunities as roughly $\mathrm{CHF}$ 210 million per year. The announcement of the commission suppression was received by the travel agencies like an abrupt calamity. To replace this commission, the agencies moved from a hidden (or vague) commission to an overt outlay for the customer. To save this expense, the customer buys on the Internet. In Switzerland, only $1 / 3$ of the voyages is still booked through travel agencies (Swiss Issues: Le marché des voyages : Entre globalisation et pression des coûts, septembre 2005, www.srv.ch).

The Internet seems to play a more and more prominent role in this industry as a direct competitor for traditional travel agencies. Actually, it seems that the assembling and the placing order steps of the process that used to be traditionally performed by the travel agents could nowadays be easily "reallocated" to the traveler. To counterattack this competition, travel agencies tend to develop customer niches, such as specific destinations, that would be left over by bigger competitors. Anyway 
pressure on cost is huge, and we don't think specialization will be sufficient for the travel agencies to survive. On the one hand, the industry fears that many small agencies might be victims of this deep crisis and its subsequent price war. On the other hand, it might also be an opportunity since clients will be looking for more value added services when consulting a travel agent. There is an urgent need for travel agents to reconsider the offering that should be put forward to the client. Opportunities lay ahead as our exploratory data collection showed it: all the travel agents interviewed told us that clients came to them because they accredited the value of their consulting services and the assistance they possibly provided. They explained it in these broad terms but they experienced difficulties to describe the more precise attributes of the specific value they delivered.

\section{The Notion of Perceived Risk: literature review}

Perceived risk has been extensively studied in the field of Marketing Services. The effect of perceived risk is believed to have a greater effect on the consumer for services (Guseman, 1981; Murray, 1991; Murray \& Schlacter, 1990). Perceived risk is a two-dimensional construct comprising the uncertainty involved in a purchase decision and the consequences of taking an unfavorable action (Bettman, 1973; Cunningham, 1967). The perception of risk has been found as totally subjective (Havlena and DeSarbo, 1990; Ross, 1975). Perceived risk was considered as a subjective expectation of loss (Mitchell and Greatorex, 1993; Peter and Ryan, 1976). Jacoby and Kaplan (1972) identified five independent types of risk: financial, performance, physical, psychological and social. Some authors recommended later to combine social and psychological types of risk as consumers felt as difficult to make the difference between them and use instead the psychosocial type of risk. Roselius (1971) added a sixth type of risk: time loss.

An example often used is that car accidents kill many more people per year than airplane crashes. However, people tend to fear airplanes more than cars. A basic two-component model of the risk perception measure was developed by Cunningham (1967). Mitchell (1998) revealed that consumers judging low probability/high consequences risks, e.g. purchasing an airline ticket, are affected more by the consequence size than by the probability, and many appear to disregard the probability altogether (Mitchell, 1998). Slovic and Lichtenstein (1968) and Horton (1976) also found that the degree of negative consequences was much more important in determining risk than the probability of their occurrence. For this reason, risk perception is the result of the probability plus the consequence as opposed to the definition of risk which is the result of the occurrence multiplied by the consequences:

\section{Risk Perception $=$ occurrence of risk + seriousness of loss.}

In this paper, we want to focus on less "serious losses" that we will call "annoyances". In fact, we make reference to a legal term "trivial annoyance" that corresponds to an uncomfortable event that cannot justify any prosecution and thus any reparation. For more "serious losses", we can assume that insurances will step in and play their role. So an annoyance risk is related to a problem of quality. In the case of travel services, the problem is that the customer will experience and sometimes suffer 
from these annoyances. The customer may be able to deal with these annoyances, but sometimes he/she may not be able to solve them. He may feel abandoned and lost in a foreign and distant destination. What if the travel agency could be helpful? How much valuable would it be? Would it be considered as a perfect "after-sales" service? Would the consumer be willing to pay for it? As an upfront payment?

Product intangibility greatly increases the degree of perceived risk (Finn, 1985; McDougall and Snetsinger, 1990; Mitchell and Greatorex, 1993; Murray and Schlacter, 1990; Zeithaml and Bitner, 2000). Intangibility is composed of 3 dimensions: physical intangibility, mental intangibility, generality (Laroche et al., 2001). Laroche et al. (2003 and 2004) studied later the impact of intangibility on perceived risk and the moderating roles of involvement and knowledge (Figure 1). They observed that there is a strong relationship between mental intangibility and perceived risk, an association between physical intangibility and perceived risk, but generality has either little or no direct impact on perceived risk. As expected (e.g. research done by Chaudhuri, 2000; Dowling, 1986), involvement has a positive moderating effect and knowledge has a negative moderating effect, i.e. the more respondents were knowledgeable, the less intangibility exerted a significant impact on perceived risk. As they were assuming, people perceive potential risks in the unknown. To reduce the perceived risk, consumers are likely to shop around to compare alternatives and ask friends and relatives for advice (Boze, 1987).

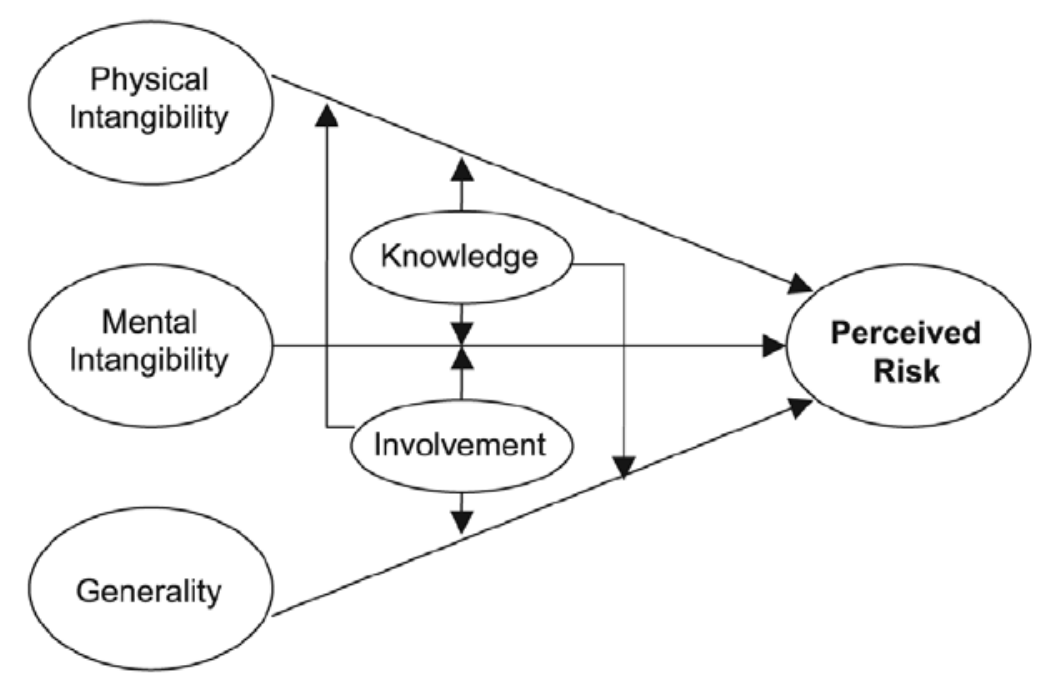

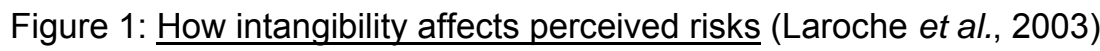

Knowledge is recognized as a characteristic that influence how consumers evaluate the risk inherent to their purchase (Murray and Schlacter, 1990). As cited by Laroche et al., Engel et al. (1993) have defined knowledge as "the information stored within memory". Park et al. (1994) have defined knowledge assessment as a judgment process in which consumers scan memory for cues in order to help them evaluate their product-related experiences. Knowledge is often conceptualized with two related dimensions: experience and expertise. Expertise is potential, latent, and virtually realizable by the consumer. Experience differentiates itself from expertise by the fact that it is concrete, operational, and actualized by the consumer. Experience is a much less useful way of reducing risk for services 
than for goods because of the heterogeneity involved in producing and consuming services (Mitchell and Prince, 1993).

Tan (1999) and Cunningham et al. (2004) claim that Internet is perceived to be riskier than the traditional service. The latter found that the perceived risk fluctuates significantly throughout the consumer buying process and that the risk premium is not constant. They explain this risk premium for Internet airline reservation by the high probability for users to make unintentional mistakes such as double booking, poor seating choices, failure to obtain electronic receipts or timely delivery of ticket, or paying too much for a nontransferable, non-refundable ticket. Moreover, mistakes are on the sole blame of the consumer who has very limited recourse for correcting errors. For Internet shoppers, information plays a key role since information search is more effective at reducing perceived risk levels. Perceptions of risk are strongly associated with reluctance to make Internet airline reservation (Kolsaker et al., 2004). In favor of Internet, it was revealed that Internet shopping technologies offer a reduction in the anxiety caused by judgmental service representatives (Meuter, Ostorm, Roundtree \& Bitner, 2000).

"Mistakes are an unavoidable feature of all human endeavor and thus also of service delivery" (Boshoff, 1997). Nevertheless, Bitner et al. (1990) showed that it is not necessarily the failure itself that leads to customer dissatisfaction. What is more likely to cause dissatisfaction is an inadequate response or a lack of response from the company. Mayer et al. (2003) showed that the customers feel on how they were treated during the process is as important as what they actually experienced. They recognize what Grönross (1984) identified as the technical dimension (what actually happened during service delivery) and as the functional component (how the service was delivered). Failure in either dimension is likely to lead to low perceived service quality.

\section{The Traveler Service Chain: Chain of Services and of Risk Events}

This descriptive part is based on in-depth interviews with fifteen consumers and fifteen travel agencies. The aim was to sketch the service chain as experienced and felt by consumers. As suggested by Booms and Bitner (1981) and Harrington (1991), in the next sections, we separated process delivery from process assembly. We will first describe the consumer buying process, and then, the parties involved in the delivery of a travel arrangement and finally, we explain the uncertainty that lies in the travel activities. Dealing with uncertainties implies dealing with risk, namely the occurrence of bad consequences and the seriousness of the damage.

\subsection{Consumer buying process: Designing a trip}

Most of the consumer buying process could be handled by the travel agency which can help the customer design or design on the behalf of the customer the delivery chain that would be later on experienced by the recipient of service. When acting on the behalf of the customer, the travel agency has to get assured that it had a clear understanding of the customer needs and expectations. 
On the continuum of evaluation for different types of products (Zeithaml and Bitner, 2000), travel services can be considered as an experience-based service which attributes can be evaluated only after purchase and consumption. According to the definition of credence-based services, i.e. credence-based services are associated with a higher degree of customization (Guiltinan, 1987; Zeithaml, 1981) and require the personal intervention of the service provider (Guiltinan, 1987), travel agency activities could also be considered as credence-based services. As cited by Mitra et al. (1999), the variability and the non-standardized nature of credence services lead to uncertainty about the actual cost and product performance (Murray and Schlater, 1990) and make it difficult for the consumer to evaluate alternatives before purchase (Guiltinan, 1987). Mitra et al. claim that high risk credence services are associated with greater information search and greater reliance on personal information sources.

Therefore, travel agency could play a key role at reducing uncertainty and risk during the information search, alternative evaluation and purchase decision phase. Most of interviewees acknowledged the fact that the travel agency was a good way of obtaining reliable information, getting access to a broad choice, designing complex travel arrangements, getting an expert insight about the alternatives and making professional choices (such as schedule, transfer). In most cases, as customers buy travel services without having experienced them, travel agencies could be the best way of obtaining the knowledge, experience and expertise that customers are missing.

We found that customers seem to appreciate this valuable competence but do not seem willing to pay for it. On the contrary, some customers gather information from various travel agencies, and then, they like going on the Internet and playing with the alternatives, designing their own package and feeling that they have "created" on their own their travel experience. They believe that the job done by travel agencies could be handled by them. Even more, some customers think that they can reduce by this way the risk of not being well understood by travel agencies. Some customers think that travel agencies may not work for their best interest but prefer to sell the highest-margin products. This phenomenon may lead to perceived unfairness of pricing which generates perceptions of financial risk (Wirtz et al., 2003). Financial risk is the predominant factor for explaining the overall risk associated with a risky purchase (Stone and Gronhaug, 1993; Forsythe and Shi, 2003).

In need recognition stage, travel agencies can only play a role of external stimulus (for instance, by communicating through promotions or special offer) and discussion partner in order to better define the customer needs and wants. Throughout the buying process, a travel agency can play the role of discussion partner and therefore, it can make the customer more willing to accept greater risk (Woodside, 1972). This tendency to accept greater risk after discussion is called the "risky-shift" phenomenon (Pruitt, 1971). This tendency is controversial and some researchers claim that the customer accepts less risk after group discussion for high-risk products (Johnson and Andrews, 1971; Woodside, 1974). Post-purchase behavior is very important for services as customers will actively 
participate to the process and experience what was decided and designed in the former stages of the buying process as described hereafter.

\subsection{Assembling a travel package: Partnering}

When organizing a journey, one has to make a series of decisions. For instance, when you book a flight, you choose an airline. By opting for an airline, you also decide for a particular route, schedule and hub. Therefore, a few decisions made in the buying process imply a myriad of activities involving some companies and a lot of subcontractors.

As the travel agency has a unique expertise, it could design a customized offer that meets or even exceeds the customer satisfaction, in the end. But what if anything went wrong? The travel package might have been designed properly; nevertheless, the customer or one of the chosen business partner (or a partner implied by the choice made, such as the airport when you choose a carrier), or some uncontrollable factors (such as a snowstorm) might cause some trouble experienced by the recipient of the travel package. Consumer will have to handle what was categorized as "product-category risk" which is the perceived risk associated with the purchase of any particular product category (i.e. travel services) as opposed to "product-specific risk" (Dowling and Staelin, 1994).

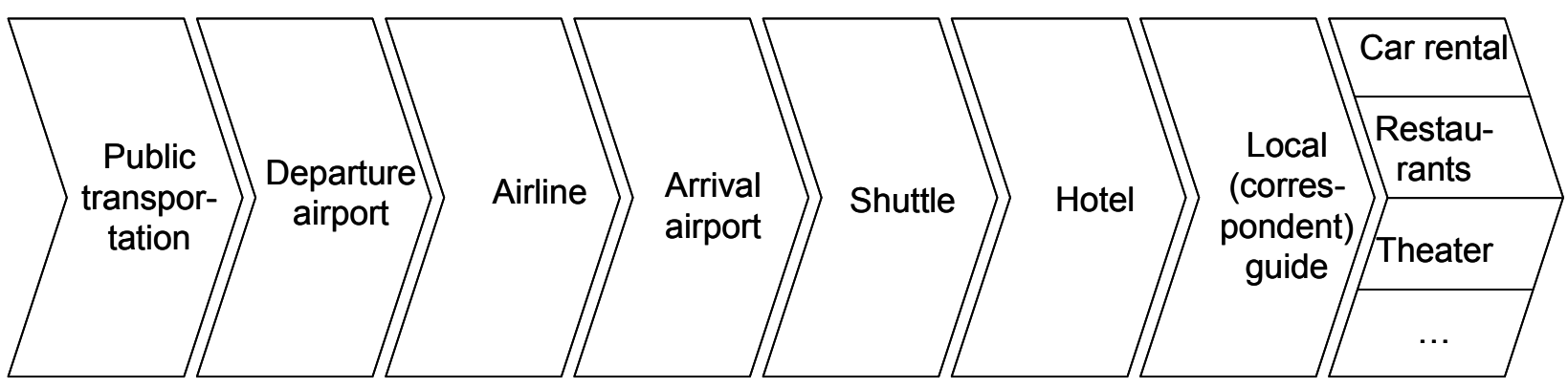

Figure 2: Companies involved in a journey

Customers might be aware of the main decision such as the airline and the hotel, but they will experience all the partners involved in the delivering of the value chain. Nevertheless, they will have to bear the consequences of some decisions made but not consciously. Organizing a travel package means assembling the activities of very different companies. Some of them are specifically picked during the purchase decision stage. When a travel agency recommends the use of a specific provider, or, even more, when a tour operator sells an all-inclusive package, companies involved in the value chain are partners in the delivery process that should lead to customer satisfaction. In this case, travel agency is specifically dealing with "product-specific risk" which is associated with a particular product (and therefore provider) purchase (Dowling and Staelin, 1994).

Some of the providers might have personally experienced by the customer or the travel agency before. Very often, they might not have. Even in the former case, as service is heterogeneous, it might be different or worse next time. When the travel agency advises the customer, it can not assure that 
everything would go perfectly fine. Through the partnering and considering all the uncontrollable factors, there is a high probability that the travel would not turn out as planned and expected.

\subsection{Uncertainty management}

Travel agencies and travelers interviewed were not aware of the risks involved in a journey. Some events may have severe consequences such as not being able to travel or losing the luggage. Others may only cause trouble, frustration or anger. Some consequences cannot be considered as serious loss but it can imply customer discontentment. According to US Department of Transportation (October 2005), the main complain categories are: flight problems (cancellations, delays), oversales, mistakes made in reservations, ticketing (mistakes made in ticketing, problems in obtaining tickets due to busy telephone lines or waiting in line), problems boarding the aircraft, fares (incorrect or incomplete information about fares, discount conditions and availability, overcharges, fare increase), refunds, luggage (lost, damaged or delayed), customer service (unhelpful, inadequate meals), advertising (unfair, misleading).

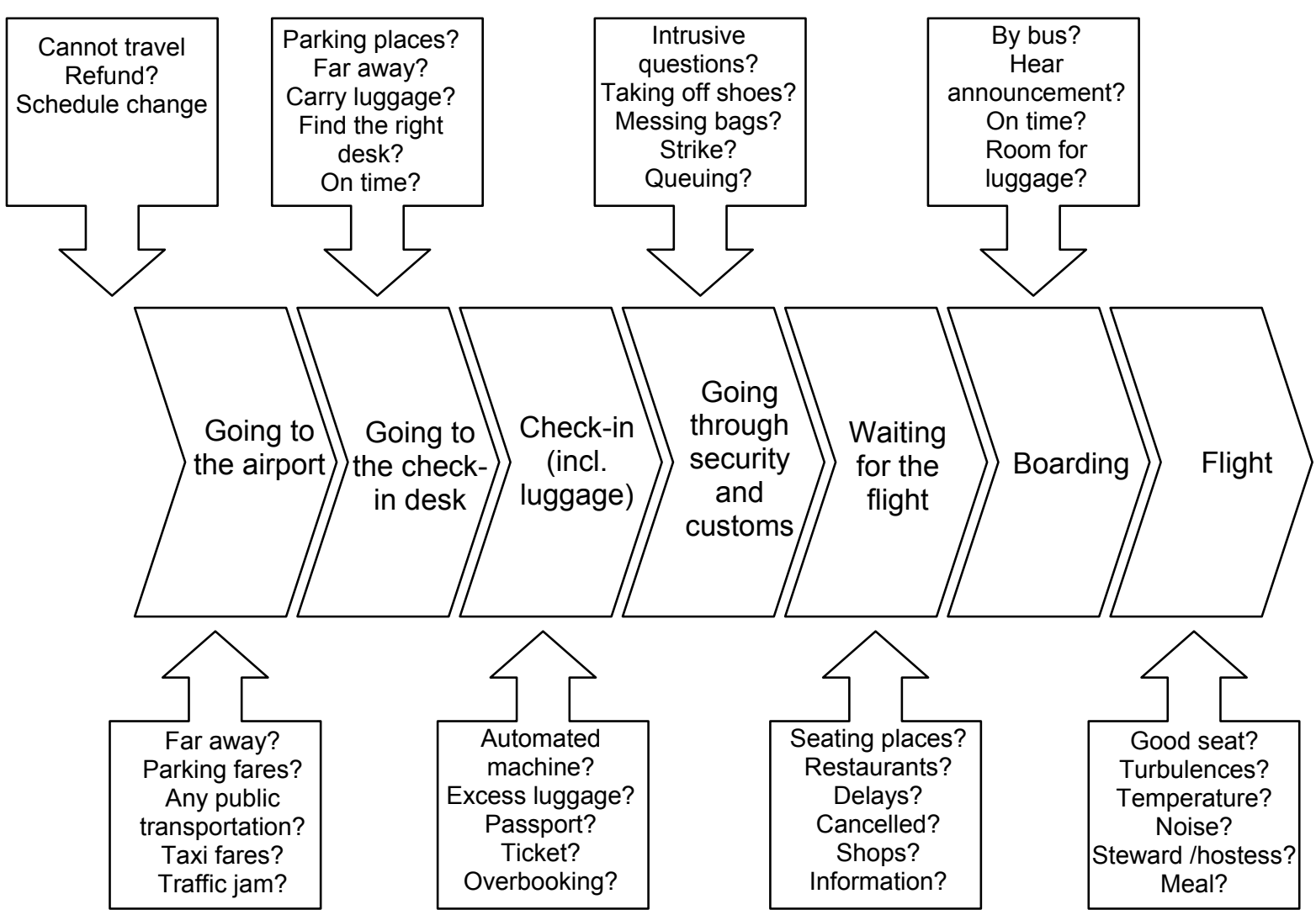

Figure 3: Activities involving customers when taking a flight

According to Heskett et al (1990), perceived risks arise in large part from customer insecurity about a lack of control of the process and the absence of tangible clues to the quality of the complex service being purchased. When traveling, customers may feel insecurity as many questions arise as they go 
through the delivery process (Figure 2). Moreover, the lack of information available in making services decisions increases the risk (Bebko, 2000), The heightened uncertainty resulting from the lack of knowledge and information implies higher perceived risk on the part of the consumer (Mitra et al., 1999). By not having the knowledge or the correct answer, the customer feels insecure about the outcome of the process. Therefore, the consumer is forced to deal with uncertainty and to the extent that the consumer realizes he/she may not attain all of his/her buying goals, risk is perceived (Mitchell, 1998). If the consumer perceives a probability of a mismatch between his/her expectations and the benefits delivered by a process, then he/she perceives a risk of not being able to fulfill his/her needs and wants (Atkinson, 1964).

Going through the activities described in Figure 3, we realize that many factors or some behaviors can induce uncertainties, discomfort or even can hinder customers carrying out the activities as expected. When asked about the trouble experienced, most of the interviewees mentioned the traditional hassle such as late luggage arrival, lost luggage, bad hotel, overbooking, flight delays and cancellations, "hidden" fees (when booking on the Internet, commissions were added at the end of the process), missed plane or connection. For most of them, consumers did not see how travel agency could be of any help at reducing the risk or minimizing the negative consequences.

Information search is a common method implemented by consumers to reduce perceived risk. The marketing literature suggests that perceived risk and information search are positively correlated (Murray, 1991). It could be more comfortable and less stressful to travel without uncertainty and unsolved questions in the back of customers' minds. Getting information before leaving and even before feeling that there is information that is missing could affect customer's perception of the process involved in delivering that service.

For many of the interviewees, Internet did not seem more risky than going through a travel agency. Internet is easily providing consumers with appropriate information and lessening the efforts needed in making purchase decisions. Internet provides and offers consumers proper access to and screening of appropriate information to minimize their search efforts in the purchase decision process (Thakor, Borsuk-Shtevi, and Kalamas as cited by Laroche et al, 2004). Nevertheless, for some customers, Internet is still risky because they feel concerned by the privacy and security issues. Research also tells us that privacy and security concerns are two most widely used antecedents of perceived risk (Hoffman, Novak and Peralta, 1999; Miyazaki and Fernandez, 2001).

\section{The Valuation of Ecological Services: Capitalizing on Experience}

The last decades have been punctuated by huge ecological catastrophes. Due to growing public concern, governments tend to take very seriously damaging events affecting the environment. Companies which are found guilty of the damages must pay huge fines in order to restore the landscapes as they used to be originally. The main difficulty is then to settle on the actual amount of the penalties. Indeed, many aspects of the damage are so specific that market mechanisms could be 
of no help to calculate a "fair price". If we think about a vista view that has been destroyed, what cost does it mean for pedestrians? If fishes are dying and consequently fishers are loosing their job, what will be the economical implications for the region? As we see, an environmental damage is multidimensional and extremely complex to price, if not impossible. The damage tends to affect people for a very long time. For instance, everyone does remember the "Exxon Valdez oil spill".

Many methods exist to value the damages done to ecosystems. They are called dollar-based valuation approaches, because they address the problem of valuing non-monetary phenomena. Consequences that are not the subject of market mechanisms are called externalities. Externalities could be damages as well as benefits (e.g. reinforced solidarity in the community facing a natural disaster). Dollar-based (or cost-based) methods are considered to be cost/benefit analyses. According to the Dictionary of Economics by Pass and Lowes (1993), cost-benefit analysis is "a technique for enumerating and evaluating the total social costs and total social benefits associated with an economic project". A typical social cost is the harm brought upon the human welfare. For instance, when you buy an airline ticket, the price does not take into account the damage done to the environment such as the emission of pollutants and the noise. These nuisances correspond to externalities as they are not priced by the market. The dollar-based valuation approaches are used when externalities are associated with a significant degree of intangibility (i.e. an ecological service). According to APAS (1996) and Torben and House (1999), there are 3 main families of dollar-based valuation approaches (an excellent presentation of these methods is available at www.ecosystemvaluation.org):

\section{Implied market decisions}

This set of methods attempt to identify the actual "Revealed Preferences". That is the case of the travel cost method, which enables the researcher to calculate the overall cost induced by the visits made by people to a recreational park. For instance, visitors use different means of transportation to reach the park. A travel cost is estimated out of parameters such the distance traveled, the average cost per mile, and the number of visits per year (see for instance Mc Kean et al., 1995). Even though, cost estimates do not correspond to the actual economic value of a given ecological service (in this case, the value of the natural park for the visitors), it is often used in court because it is seen as an objective approach. Another well known approach belonging to this family is the hedonic pricing method. This latter method is based on statistical techniques such as the regression analysis, where the significant and measurable independent variables (also called characteristics) determine the price of a given ecological service (see for instance, Ready and Abdalla, 2005). In this case, we base the evaluation on the actual behavior of people.

\section{Experimental market techniques}

Experimental market techniques are also called Contingent Valuation Methods (CVM). A CVM is a questionnaire-based approach to assess the Willingness To Pay (WTP). As opposed to the first family 
of methods that assess "Revealed Preferences", it is considered to be a "Stated Preferences" approach. Hypothetical scenarios are developed simulating a purchase process (e.g. bidding games) of a given ecological service. Next, the WTP is assessed through a typical survey research. This method is also quite controversial (Schkade and Payne, 1993). Indeed, many studies question the validity and reliability of measuring the true WTP (see for instance Bateman et al., 1993, and also Azevedo et al, 2003). Nevertheless, it is the only approach available to assess "non use values" (Diamond and Hausman, 1993). For instance people might be asked how much they would be Willing To Pay to maintain a forest. Here, we are using the attitudes of people to asses the WTP.

\section{Surrogate market methods}

The substitute cost, replacement cost and damage cost avoided methods assess the value of an ecological service by identifying corresponding surrogate options and associated costs (see for instance, Abdalla, 1994, Strange et al., 2004). For instance, if an oil spill would destroy a species in a lagoon, what would be the cost to repopulate it? This method presents the advantages of simplicity and practicality. The main disadvantage is that the actual WTP regarding the estimated cost is often very low. Anyway, this gives a starting value and the purpose of our approach is at this point not to price a service but to provide risk information to manage the perceived risk. The other well known surrogate market method is the shadow price approach. Shadow prices correspond to the marginal cost of given resources used to produce energy services for instance. They can be obtained by calculating the dual prices of mathematical problems (see for instance Bahn et al., 1998, who use the dual prices of stochastic programs to determine the shadow prices of $\mathrm{CO} 2$ emissions).

Every family of methods tends to serve a specific purpose. The travel cost method is adapted to cases where people travel to visit a recreational park. In service marketing literature, it is specifically considered as a servicescape. The CVM is the method of choice for valuing "non-uses". Replacement cost and substitute cost and damage cost avoided methods will appropriately serve our needs because if a broken link appears in the travel service chain, it must be replaced or substituted by another kind of link. Indeed, there is an intimate link with the design of services because a substitution (surrogate) market is established in order to value non-monetary damages. Consequently in this paper, we have chosen the replacement cost, substitute cost and damage cost avoided methods.

In conclusion, we must recall that the main drawback of these approaches remains the actual Willingness To Pay (WTP) once the value of the service has been assessed. However, as these methods are nowadays imposed by most regulators to assess externalities emanating from big projects, we can benefit from huge experience gathered in court proceedings, as well as in environmental sciences research papers. 


\section{A Framework to Design Risk Management Services for the Traveler}

In this section, we refer to professional bodies such as $\operatorname{COSO}$ (www.coso.org) and IIA (thellA.org) that are specifically dealing with risk control and management. We believe that professional guidance is relevant in our context to make our approach more feasible. The sequence of a risk management approach is often stated as follows: Identification of risks, Prioritization of risks, Establishing internal control system (ICS) and risk ownership, Risk management per say (transfer, eliminate, mitigate, accept), Actions plans and Risk communication. We adapt this sequence on two simple (fictitious) cases by including the replacement cost and substitute cost and damage cost avoided methods.

The first case applies the replacement cost and substitute cost methods only. We assume that a Professor must teach at the University of Edinburgh from March 10, $9.30 \mathrm{am}$. On March 9, she must attend an important meeting in Geneva until $5 \mathrm{pm}$. So she is not able to catch the direct flight to Edinburgh departing at 3pm. Her travel agent finds a suitable flight on the Internet and proposes the following time schedule:

$\begin{array}{lllll}\text { Geneva } & 18.15 & \rightarrow & \text { London Luton } & 19.05 \\ \text { London Luton } & 20.45 & \rightarrow & \text { Edinburgh } & 22.00\end{array}$

We now indicate the sequence of the replacement cost and substitution cost methods adapted to this case.

1. Inventorying risks that might arise along the travel service chain. The first advice given by the travel agent is to bring along only a carry-on luggage because the time between connections could be tight in case of delays and moreover this low cost airline do not handle baggage between flights. So referring to the risk process, this advice enables the traveler to reduce the probability (i.e. mitigation acts either on probability or damage) of missing the connecting flight. The travel agent will also tell her to check that her identity card is still valid, because with this flight connection she must go through the custom office first when arriving in England. However, the main risks in the sequence are:

- $\quad$ First, to miss the flight at Geneva airport. This could happen, for instance, because the taxi is stuck in a traffic jam, or because the plane has been cancelled due heavy snowfalls.

- Second, to miss the connection at London Luton airport. This could happen, for instance, because the first risk would happen, or because the Geneva flight was very late.

2. Identifying alternatives for substitution or replacement. The travel agent has found out that another flight leaves Geneva to London Luton at $9.55 \mathrm{pm}$ and arrives at $10.35 \mathrm{pm}$. So if the traveler misses the 18.15 flight she would be able to arrive in London late in the evening. He then identifies 2 options to enable his client to show up on time the following day at the University of Edinburgh: 
- Replacement option. There is a flight from London Gatwick to Edinburgh departing the following day at $6.45 \mathrm{am}$ and arriving at $8.15 \mathrm{am}$. So the traveler would take the tube and then the express train to Gatwick, book a room in a hotel in the vicinity of Gatwick airport. She would wake up early to catch the plane to Edinburgh and if the plane is on time, take a taxi to the University.

- Substitute option. At Luton airport, there is rental car business open until midnight. So as long as the Professor has not forgotten to take her driver license, she could drive 7 hours and arrive very early in the morning in Edinburgh.

\section{In the third step of the replacement and substitute cost methods, the travel agent must calculate the} cost of alternatives.

- $\quad$ Replacement option costs. The travel agent adds up the costs of the new Geneva flight to London, plus the tube and train tickets, plus a night at the hotel, plus the new flight to Edinburgh, and extra expenses. He ends up with a total amount of 150 pounds if the additional flight tickets are bought today (i.e. the pricing of the airline company is based on yield management). So in that case the traveler manages risks in an "ex-ante" manner. He obtains a total of 245 pounds, if he buys the tickets only after her client would miss her connection (assuming a 24/24 service). So in that latter case, risks are handled in an "ex-post" manner.

- $\quad$ Substitute option costs. The travel agent adds up the costs of the new Geneva flight to London, plus the cost of the rental car, plus gasoline and extra expenses, minus the taxi in Edinburgh. $\mathrm{He}$ ends up with a total amount of 126 pounds if the additional flight tickets are bought today and 183 pounds if bought in case the damage would happen.

\section{Verifying that the client would pay for the replacements or substitutes}

- Replacement option costs. The Professor understands that this option represents a good risk protection, although there is still a significant residual risk (i.e. "zero risk" does not exist), since the new morning flight to Edinburgh could be cancelled or delayed. In terms of replacement costs, the client acknowledges that the total amount is reasonable. Moreover, she thinks that an unexpected short night in a hotel near Gatwick airport will enable her to properly rest before her classes.

- Substitute option costs. The Professor recognizes that this option represents an even better risk protection because she won't be subject to flight delays or cancellation. In terms of substitute costs, this is also reasonable and sufficiently close to the replacement option costs to be indifferent. On the other hand, she is afraid to drive in UK and thinks that she would arrive very tired in Edinburgh.

So finally, the Professor asks her travel agent to consider the replacement option and to buy it now. So compared to the risk management process presented in the beginning of the section, the process is similar except that the "risk management per se" phase is particular. Indeed, the travel agent is not 
able to avoid the risk, neither to reduce the probability or the damage of the risk (i.e. mitigation). $\mathrm{He}$ simply looks for surrogate (replacement or substitution) options. This is the main advantage of these methods, which are simple, accessible, and intuitive for the travel agent having no knowledge of risk management techniques. Moreover, the calculation of options costs is straightforward and objective. On the other hand, these costs estimates do not correspond to the real (or economical) value associated to the risk service. Only CVM methods would give a more accurate estimate (even though these methods are considered to be controversial by many researchers) of service, by calculating the WTP. Nevertheless, going trough this risk management process increases the awareness of perceived risks since, as indicated by the literature review of Section 3, a better understanding of risks and associated costs should affect the purchasing behavior of the client. At the same time the travel agent is designing customized services for his client. If applied regularly with all clients, a knowledge management system could be set up, which would enable the travel agency to exploit economies of scale and of scope. We could then imagine that the price of this new kind of services represents a fraction of the replacement or substitute costs.

In the same way another case could be developed where the damage cost avoided method is applied. Indeed, this latter method is part of the same family. In our interviews, we have heard several similar situations where people traveled from Europe to South America. These persons had booked their flights on the Internet. Unfortunately, when arriving in the US, they could not take their connecting flight because they had no visa to enter the US. The Internet had not informed them about this problem. Here, we could apply the damage cost avoided method. The process is the same as the replacement and substitute cost methods presented above, except that the cost is estimated based on the potential damage costs (e.g., cost to issue a new visa, hotel nights, ....).

\section{Conclusion}

In the past, most of travel agencies revenues was generated via commissions they earned by selling airline tickets. Nowadays they must rely on other sources of income in order to survive. Unfortunately, the generally adopted pricing scheme is to charge a single fee whatever the service provided to the client. Nevertheless, our first exploratory research indicates that the customer is not willing to pay this commission because he/she was used to receive the counseling services for "free".

In this paper, we proposed a methodology to design risk management services that could be provided by the travel agent to the client. Design of services research calls for multidisciplinary approaches including marketing, organizational behavior, psychology, corporate strategy, functional strategy, information systems, operations research, and economics (Hill et al., 2002). As such, our methodology combines approaches borrowed from the risk management and audit professions as well as research from the environmental sciences and services marketing. Indeed, we apply dollar-based valuation methods to manage the risks encountered along the service chain. In particular, we have opted for the replacement and substitute cost methods as well as the damage cost avoided technique because of their simplicity and wide acceptance. This risk framework service enables then the travel agent to 
provide sound risk management for his/her clients. Another advantage of this proposal is that we benefit from a lot of experiments that have been conducted in environmental sciences.

Future research should be conducted in order to investigate a wider range of behavioral intentions, such as future information search or Willingness To Pay a higher price, should be tested (Mitra et al., 1999). So as to help to assess the willingness to pay for higher added value services, stated preferences method and contingent valuation method should be explored.

\section{References}

Abdalla, C. (1994). "Groundwater values from avoidance cost studies: Implications for policy and research", American Journal of Agricultural Economics, Vol. 76, 1062-67

APAS (1996). Evaluation - Road transport, Directorate General for Transport, Commission of the European Communities, Brussels

Atkinson, J.W. (1964). An Introduction of Motivation, Van Nostrand, New York, NY

Azevedo, C., Herriges, J. and Kling, C. (2003). "Combining revealed and stated preferences: Consistency tests and their interpretations", American Journal Agricultural Economics, Vol. 85 No. 3, August, 525-37

Bahn, O., Fragnière, E. and Kypreos, S. (1998). "Swiss energy taxation options to curb CO2 emissions", European Environment, Vol. 8, 94-101

Bateman, I., Willis, K. and Garrod, G. (1993). "Consistency between contingent valuation estimates: A comparison of two studies of UK national parks", Regional Studies, Vol. 28 No. 5, 457-74

Bebko, C.P. (2000). "Service intangibility and its impact on consumer expectations of service quality", Journal of Services Marketing, 14 No. 1, 9-26

Bettman, J.R. (1973). "Perceived risk and its components: a model and empirical test", Journal of Marketing Research, Vol. 10, May, 184-90

Bitner, M.J., Booms, B.H. and Tetreault, M.S. (1990). "The service encounter: diagnosing favorable and unfavorable incidents", Journal of Marketing, Vol. 54, January, 71-84

Booms, B. and Bitner, M. (1981). "Marketing strategies and organization structures for service firms", in Donnelly, J. and George, W. (Eds), Marketing of Services, American Marketing Association, Chicago, IL 
Boshoff, C.R. (1997). "An experimental study of service recovery options", International Journal of Service Industry Management, Vol. 8 No. 2, 110-30

Boze, B.V. (1987). "Selection of legal services: an investigation of perceived risk", Journal of Professional Services Marketing, Vol. 3 No. 1, 287-97

Chaudhuri, A. (2000). "A macro analysis of the relationship of product involvement and information search: the role of risk", Journal of Marketing Theory and Practice, Vol. 8 No. 1, 1-15

Cunningham, S.M. (1967). "The major dimensions of perceived risk”, in Cox, D.F. (Ed.), Risk Taking and Information Handling in Consumer Behavior, Boston University Press, Boston, MA, 102-8

Cunningham, L.F., Gerlach, J., Harper, M. D. (2004). "Assessing perceived risk of consumers in Internet airline reservations services", Journal of Air Transportation, Vol. 9, No 1, 21-35

Diamond, P. A. \& Hausman, J. A. (1993). "On Contingent Valuation Measurement of Nonuse Values", in J. A. Hausman (ed.) Contingent Valuation: A Critical Assessment; Elsevier Science Publishers B.V.

Dowling, G.R. (1986). "Perceived risk: the concept and its measurement", Psychology and Marketing, Vol. 13 No. 3, 183-209

Dowling, G. R. and Staelin, R. (1994). "A model of perceived risk and risk-handling activities", Journal of Consumer Research, Vol. 21, June, 119-34

Engel, J.F., Blackwell, R.D. and Miniard, P.W. (1993). Consumer Behavior, 7th ed., Dryden Press, Chicago, IL

Finn, A. (1985). "A theory of the consumer evaluation process for new product concepts", Research in Consumer Behavior, Vol. 1, 35-65

Forsythe, S. and Shi, B. (2003). "Consumer patronage and risk perceptions in Internet shopping", Journal of Business Research, Vol. 56, 867-75

Grönroos, C. (1984). "A service quality model and its marketing implications", European Journal of Marketing, Vol. 18 No. 4, 36-44

Guiltinan, J.P (1987).. "The price bundling of services: a normative framework", Journal of Marketing, Vol. 51, 74-85

Guseman, D. S. (1981). "Risk perception and risk reduction in consumer services". In J.H. Donnelly, et al. (Eds.). Marketing of Services, Chicago, IL: American Marketing Association 
Harrington, H. (1991). Business Process Improvement: The Breakthrough Strategy for Total Quality, Productivity and Competitiveness, McGraw-Hill, New York, NY

Havelena, W.J. and DeSarbo, W.S. (1990). "On the measurement of perceived consumer risk", Decision Sciences, Vol. 22, 927-39

Heskett, J., Sasser, W. and Hart, C. (1990). Service Breakthroughs: Changing the Rules of the Game, Free Press, New York, NY, and Collier Macmillan, Toronto

Hill, A.V., Collier, D. A., Froehle, C.M., Goodale, J.C., Metters, R.D. and Verma, R. (2002). "Research opportunities in service design", Journal of Operations Management, Vol. 286, 1-14

Hoffman, D., Novak, P. and Peralta, M. (1999). "Building consumer trust online", Communications of the ACM, 42 No.4, 80-85

Holvad, T. (1999). Contingent Valuation Methods: Possibilities and Problems, Working Paper, FEEM, Roma

Horton, R.L. (1976). "The structure of decision risk: some further progress", Journal of the Academy of Marketing Science, Vol. 4 No. 4, Fall, 694-706

Jacoby, J. and Kaplan, L. (1972). "The components of perceived risk", in Venkatesan, M. (Ed.), Proceedings 3rd Annual Conference Association for Consumer Research, Chicago, IL, 382-93

Johnson, D.L. and Andrews, I.R. (1971). "Risky-shift phenomenon as tested with consumer products as stimuli", Journal of Personality and Social Psychology, Vol. 20, August, 328-85.

Kolsaker, A., Kelley, L.L. and Choy, P.C. (2004). "The reluctant Hong Kong consumer: purchasing travel online", International Journal of Consumer Studies, Vol. 28 No. 3, 295-304

Laroche, M., Bergeron, J. and Goutaland, C. (2001). "A three-dimensional scale of intangibility", Journal of Service Research, Vol. 4 No. 1, 26-38

Laroche, M., Bergeron, J., Goutaland, C. (2003). "How intangibility affects perceived risk: the moderating role of knowledge and involvement", Journal of Services Marketing, Vol. 17 No. 2, 122-140

Laroche, M., McDougall, G.H.G., Bergeron, J., and Yang, Z. (2004). "Exploring how intangibility affects perceived risk", Journal of Service Research, Vol. 6 No. 4, May, 373-89 
Mayer, K.J., Bowen, J.T. and Moulton, M.R. (2003). "A proposed model of the descriptors of service process", Journal of Services Marketing, Vol. 17 No. 6, 621-639

McDougall, G.H.G. and Snetsinger, D.W. (1990). "The intangibility of services: measurement and competitive perspectives", The Journal of Services Marketing, Vol. 4, Fall, 27-40

McKean J., Walsh R. and Johnson, D. (1996). "Closely related good prices in the travel cost model", American Journal Agricultural Economics, Vol. 78, August, 640-6

Meuter, M. L., Ostorm, A. L., Roundtree, R. I. and Bitner, M.J. (2000). "Self-service technologies: Understanding customer satisfaction with technology-based service encounters". Journal of Marketing, Vol. 64, July, 50-64

Miyazaki, A. D. and Fernandez, A. (2001). "Consumer perceptions of privacy and security risks for online shopping", Journal of Consumer Affairs, Vol. 35 No. 1, 27-44

Mitchell, V-W. (1998). "A role for consumer risk perceptions in grocery retailing", British Food Journal, Vol. 100 No. $4,171-83$

Mitchell, V.W. (1999). "Consumer perceived risk: Conceptualizations and models", European Journal of Marketing, Vol. 33 No. 1/2, 163-95

Mitchell, V.W. and Greatorex, M. (1993). "Risk perception and reduction in the purchase of consumer services", The Service Industries Journal, Vol. 13, October, 179-200

Mitchell, V.W. and Prince, G.S. (1993). "Retailing to experienced and inexperienced consumers: a perceived risk approach", International Journal of Retail \& Distribution Management, Vol. 12 No. 5, 1021

Mitra, K., Reiss, M. and Capella, L. (1999). "An examination of perceived risk, information search and behavioral intentions in search, experience and credence services", Journal of Services Marketing, Vol. 13 No. 3, 208-28

Murray, K.B. (1991). "A test of services marketing theory: consumer information acquisition activities", Journal of Marketing, Vol. 55 No. 1, 11-25

Murray, K. B. and J. L. Schlacter. (1990). "The impact of services versus goods on consumers' assessment of perceived risk". Journal of the Academy of Marketing Science, Vol. 18 No. 1, 51-65

Parasuraman, A, Zeithaml, V. A. and Berry, L. L. (1985). "A conceptual model of service quality and its implications for future research". Journal of Marketing, Vol. 49, 41-50 
Pass, C. and Lowes, B. (1993). Dictionary of Economics, Bookmart Ltd, Leicester

Peter, J.P. and Ryan, M.J. (1976). "An investigation of perceived risk at the brand level", Journal of Marketing Research, Vol. 13, May, 184-88

Pruitt, D.G. (1971). "Conclusions: towards an understanding of choice shifts in group discussion", Journal of Personality and Social Psychology, Vol. 20, August, 495-510

Ready, C. and Abdalla, C. (2005). "The amenity and disamenity impacts of agriculture: Estimates from a hedonic pricing model", American Journal Agricultural Economics, Vol. 87 No. 2, May, 314-26

Ross, I. (1975). "Perceived risk and consumer behavior: a critical review", Conference of the American Marketing Association, Vol. 1, 19-23

Schkade, D. A. and Payne, J. W. (1993). "Where Do the Numbers Come from: How People Respond to Contingent Valuation Questions"; in J. A. Hausman (ed.) Contingent Valuation: A Critical Assessment; Elsevier Science Publishers B.V.

Slovic, P. and Lichtenstein, S. (1968). "Relative importance of probabilities and payoff in risk taking", Journal of Experimental Psychology Monograph, Vol. 78, November, 1-18

Stone, R.N. and Grønhaug, K. (1993). "Perceived risk: further considerations for the marketing discipline", European Journal of Marketing, Vol. 27 No. 3, 39-50

Strange, E., Allen, P., Beltman, D., Lipton, J. and Mills, D. (2004). "The habitat-based replacement cost method for assessing monetary damage resource injuries", Fisheries, Vol. 29, No. 7, 17-23

Tan, S.J. (1999). "Strategies for reducing consumers' risk aversion in Internet shopping", Journal of Consumer Marketing, Vol. 16 No. 2, 163-80

Thakor, M.V., Borsuk-Shtevi, W. and Kalamas, M. (2004). "Hotlists and Web browsing behavior - An empirical investigation," Journal of Business Research, Vo. 57, 23-35

Wirtz, J., Kimes, S.E., Ho, J.P.T. and Patterson, P.G. (2003). "Revenue management: resolving potential customer conflicts", Journal of Revenue and Pricing Management, Vol. 2 No. 3, 216-26

Woodside, A.G. (1972). "Informal group influences on risk taking", Journal of Marketing Research, Vol. 9, May, 223-5 
Woodside, A.G. (1974). "Is there a generalised risky shift phenomenon in consumer behaviour?", Journal of Marketing Research, Vol. 11, May, 225-6

Zeithaml, V.A. (1981). "How consumer evaluation processes differ between goods and services", in Donnelly, J.H. and George, W.R. (Eds), Marketing of Services, American Marketing Association, Chicago, IL, 186-90

ZeithamI V.A. and Bitner, M.J. (2000). Services Marketing: Integrating Customer Focus across the firms, 2nd ed., McGraw-Hill, New York, NY 
Cahiers de recherche du Centre de Recherche Appliquée en Gestion (CRAG) de la Haute Ecole de Gestion - Genève

\section{(C) 2006}

CRAG - Centre de Recherche Appliquée en Gestion

Haute école de gestion - Genève

Campus de Battelle, Bâtiment $\mathrm{F}$

7, route de Drize - 1227 Carouge - Suisse

$\bowtie$ crag@hesge.ch

www.hesge.ch/heg/crag

(ग) +41223881818

悬 +41223881740

\section{6}

- $\quad N^{\circ}$ HES-SO/HEG-GE/C--06/1/1--CH

Andrea BARANZINI

Damien ROCHETTE

"La demande de récréation pour un parc naturel

Une application au Bois de Pfyn-Finges, Suisse"

- $\mathrm{N}^{\circ} \mathrm{HES}-\mathrm{SO} / \mathrm{HEG}-\mathrm{GE} / \mathrm{C}--06 / 2 / 1--\mathrm{CH}$

Giovanni FERRO LUZZI

Yves FLÜCKIGER

Sylvain WEBER

"A Cluster Analysis of Multidimentional Poverty in Switzerland"

- $\quad \mathrm{N}^{\circ} \mathrm{HES}-\mathrm{SO} / \mathrm{HEG}-\mathrm{GE} / \mathrm{C}--06 / 3 / 1--\mathrm{CH}$

Giovanni FERRO LUZZI

Sylvain WEBER

"Measuring the Performance of Microfinance Institutions"

- $\quad \mathrm{N}^{\circ}$ HES-SO/HEG-GE/C--06/4/1--CH

Jennifer D'URSO

"L'eau de boisson :

Aspects logistiques et attitude du consommateur"

- $\quad \mathrm{N}^{\circ}$ HES-SO/HEG-GE/C--06/5/1--CH

Jennifer D'URSO

"La gestion publique de l'eau en Suisse"

- $\quad \mathrm{N}^{\circ} \mathrm{HES}-\mathrm{SO} / \mathrm{HEG}-\mathrm{GE} / \mathrm{C}-\mathrm{-06/6/1-- \textrm {CH }}$

Philippe THALMANN

Andrea BARANZINI

"Gradual Introduction of Coercive Instruments in Climate Policy" 
- $\quad \mathrm{N}^{\circ}$ HES-SO/HEG-GE/C--06/7/1--CH

Andrea BARANZINI

Caroline SCHAERER

José RAMIREZ

Philippe THALMANN

"Feel it or Measure it.

Perceived vs. Measured Noise in Hedonic Models"

- $\quad \mathrm{N}^{\circ} \mathrm{HES}-\mathrm{SO} / \mathrm{HEG}-\mathrm{GE} / \mathrm{C}--06 / 8 / 1--\mathrm{CH}$

José RAMIREZ

Anatoli VASSILIEV

"An Efficiency Comparison of Regional Employment Offices Operating under Different

Exogenous Conditions"

- $\quad \mathrm{N}^{\circ} \mathrm{HES}-\mathrm{SO} / \mathrm{HEG}-\mathrm{GE} / \mathrm{C}--06 / 9 / 1--\mathrm{CH}$

José RAMIREZ

Joseph DEUTSCH

Yves FLÜCKIGER

Jacques SILBER

"Export Activity and Wage Dispersion: The Case of Swiss Firms"

- $\quad N^{\circ} \mathrm{HES}-\mathrm{SO} / \mathrm{HEG}-\mathrm{GE} / \mathrm{C}--06 / 10 / 1--\mathrm{CH}$

Joëlle DEBELY

Gaëtan DERACHE

Emmanuel FRAGNIERE

Jean TUBEROSA

"Rapport d'enquête : sondage Infobésité"

- $\quad \mathrm{N}^{\circ} \mathrm{HES}-\mathrm{SO} / \mathrm{HEG}-\mathrm{GE} / \mathrm{C}--06 / 11 / 1--\mathrm{CH}$

Andrea BARANZINI

José RAMIREZ

Cristian UGARTE ROMERO

"Les déterminants du choix de (dé)localisation des entreprises en Suisse"

- $\quad \mathrm{N}^{\circ} \mathrm{HES}-\mathrm{SO} / \mathrm{HEG}-\mathrm{GE} / \mathrm{C}-\mathrm{-06/12/1-- \textrm {CH }}$

Catherine EQUEY BALZLI

Jean TUBEROSA

David MARADAN

Marie-Eve ZUFFEREY BERSIER

"Étude du comportement des PME/PMI suisses en matière d'adoption de système de gestion intégré.

Entre méconnaissance et satisfaction."

- $\quad \mathrm{N}^{\circ} \mathrm{HES}-\mathrm{SO} / \mathrm{HEG}-\mathrm{GE} / \mathrm{C}--06 / 13 / 1--\mathrm{CH}$

Joëlle DEBELY

Magali DUBOSSON

Emmanuel Fragnière

"The pricing of the knowledge-based services : Insight from the environmental sciences" 
- $\quad \mathrm{N}^{\circ} \mathrm{HES}-\mathrm{SO} / \mathrm{HEG}-\mathrm{GE} / \mathrm{C}-\mathrm{-07/1/1--CH}$

Andrea BARANZINI

Caroline SCHAERER

"A Sight for Sore Eyes

Assessing the value of view and landscape use on the housing market" 